\title{
VOCALIZACIONES Y ÉXITO REPRODUCTIVO DE POLIOPTILA DUMICOLA (AVES: POLIOPTILIDAE) EN EL VALLE DE INUNDACIÓN DEL RÍO PARANÁ MEDIO: IMPLICANCIAS DE LA CONTAMINACIÓN ACÚSTICA
}

Evelina J. Leon

evelinaleon903@hotmail.com

Doctorado en Ciencias Biológicas

Director: Dr. Adolfo H. Beltzer

Co-director: Dra. Paola M. Peltzer

Lugar de realización: Laboratorio de Conservación y Biodiversidad de tetrápodos- Instituto Nacional de Limnología (INALI-UNL-CONICET). Fecha de la defensa: 20 de marzo de 2019

\section{RESUMEN}

El canto de las aves resulta un modelo particularmente efectivo para estudiar como las señales acústicas se relacionan con el éxito reproductivo y este punto es uno de los que más ha atraído la atención de ecólogos y ornitólogos a nivel mundial, principalmente por la complejidad y variedad en los comportamientos específicos. La información bibliográfica documenta el canto del macho puede ser un indicador de la capacidad de obtener recursos, la salud, la capacidad de aprendizaje y desarrollo para adaptarse al estrés, la atención a las hembras o las habilidades sociales que pueda tener. Por otro lado, la transformación de los ecosistemas naturales realizada por el hombre ha modificado drásticamente los entornos comunicativos de las aves. Se ha determinado que uno de los factores que más influye en el bienestar de las aves en las cercanías a las rutas es el ruido excesivo del tráfico. De una manera u otra, la capacidad de las aves canoras para optimizar la expresión del canto en respuesta al ruido antropogénico puede depender de la especie y de la capacidad plástica de señalización. La información bibliográfica que documenta el efecto de la contaminación acústica, generada por actividades antrópicas sobre la fauna silvestre es abundante para otros países y casi inexistente para Argentina y ambientes del río Paraná medio donde el avance de la frontera urbana y agrícola es alarmante. El objetivo general de este estudio fue analizar las vocalizaciones de aves de la Familia Polioptilidae (Passeriformes), particularmente de la Tacuarita azul (Polioptila dumicola) en el valle de inundación del río Paraná Medio y relacionarlas con el éxito reproductivo intraespecífico en ambientes con distintos grados de contaminación acústica y fisonomías. El estudio se realizó en la Isla Peruhil, sitio que limita con la ruta nacional $N^{\circ} 168$ y abarcó tres temporadas reproductivas entre agosto 2014 y febrero 2017. Se estimó la relación entre el canto de $P$. dumicola y el éxito reproductivo, la influencia de la intensidad del ruido y el porcentaje de cobertura vegetal en el canto y éxito reproductivo de la especie. En general, se observó que los machos de la especie seleccionada poseen un amplio repertorio de vocalizaciones (cantos y llamadas) 
así como también un amplio repertorio de notas con las que construyen la variedad de cantos que poseen. Se determinó que algunas características del canto de los machos (duración del canto, frecuencia máxima y mínima) están relacionadas directamente con el éxito reproductivo. Demostrando que aqueIlos individuos que presentaron mayor número de notas, frecuencia máxima y enfatizada fueron los que obtuvieron mayor éxito reproductivo y para el caso de la frecuencia mínima se encontró una correlación negativa ya que los individuos con mayor éxito reproductivo presentaron menor valor en esta variable. Por otro lado, el número de pichones por zona con diferentes intensidades de ruido no presentó diferencias, en cambio si lo hicieron las medidas morfométricas, registrándose pichones de mayor peso y tamaño en la Zona A que es la contaminada acústicamente. En relación a la influencia del ruido en el éxito reproductivo se pudo observar que los nidos exitosos fueron significativamente mayores en las zonas más alejadas de la fuente de ruido. En cuanto a la influencia del ruido y la cobertura vegetal en las vocalizaciones de los machos de $P$. dumicola, se observó que ambas influyeron en la duración de notas e intensidad del canto. Se pudo determinar que las zonas con menor cobertura vegetal presentaron mayor duración del canto sucediendo lo contrario con la intensidad (mayor cobertura, mayor intensidad). Por otro lado, la variable intensidad del canto fue la única influenciada por el ruido del tráfico, demostrando que las zonas con mayor ruido registraron mayor intensidad en los mismos. Las variables acústicas frecuencia máxima, mínima, enfatizada, duración de notas e intensidad presentaron diferencias significativas entre las tres zonas con diferentes niveles de contaminación acústica.

El presente estudio muestra resultados inéditos sobre el amplio repertorio vocal de Polioptila dumicola. Además, aporta las primeras evidencias que indican que los machos de esta especie ajustan parámetros de sus vocalizaciones y comportamiento reproductivo a la presencia de contaminación acústica en su hábitat. Posiblemente este tipo de contaminación, influya sobre el tamaño corporal de los pichones de la población monitoreada debido al estrés ambiental percibido por sus padres durante la etapa de incubación. Provocando cambios morfológicos significativos como resultado de un efecto compensatorio a estas situaciones de estrés.

Además, tanto la contaminación acústica como los cambios en la fisonomía ambiental producto de la degradación del hábitat provocan modificaciones en algunos parámetros acústicos de sus vocalizaciones. Esto resulta en cuadruplicar la eficiencia de la audición provocando importantes cambios fisiológicos y de comportamiento para lograr cumplir con estrategias que permitan comunicarse en ambientes ruidosos. Las evidencias obtenidas en esta tesis demuestran que puede considerarse al ruido de la ruta nacional $\mathrm{N}^{\circ} 168$ como un desencadenante de efectos negativos sobre Polioptila dumicola y que podría generar alteraciones de la comunidad de aves en la región. 


\section{ABSTRACT}

\section{Vocalizations and reproductive success of Polioptila dumicola (Birds: Polioptilidae) in the flood valley of the middle Paraná River: implications of noise pollution}

The song of birds is an effective model to study the relationship between acoustic signals and reproductive success. But the transformation of natural ecosystems, particularly traffic noise, has changed the communicative environments of birds. The bibliographic information documenting the effect of noise pollution on wildlife is almost non-existent for Argentina and in environments of the Paraná Medio River.

The general objective was to analyze the vocalizations of birds of the blue Tacuarita (Polioptila dumicola) in the flood valley of the middle Paraná River and to relate them to the intraspecific reproductive success in environments with different degrees of acoustic contamination and physiognomies.

It was observed that males have a wide repertoire of songs and calls and that some singing parameters influence reproductive success. In addition, chicks of greater weight and size were recorded in the area, as well as a smaller number of successful nests.

Regarding the influence of noise and vegetation cover on the vocalizations of the males, both influenced the length of notes and intensity of the song.

This study shows unpublished results about the wide vocal repertoire of Polioptila dumicola and the adjustments it must make in the presence of acoustic contamination in its habitat. In addition, possibly the body size of the chicks is influenced by the environmental stress perceived by their parents during the incubation stage.

The obtained evidences show that the noise of the national route $N^{\circ} 168$ is a trigger of negative effects on Polioptila dumicola and could generate alterations in the community of birds in the region. 